\title{
THE CREATION OF ABELENGRO: A CROSS-CULTURAL ART MUSIC COMPOSITION
}

\author{
Justice Owusu-Ansah and Emmanuel Obed Acquah \\ ${ }^{1}$ Saint Ambrose College of Education, Dormaa Akwamu \\ ${ }^{2}$ Department of Music Education, University of Education, Winneba
}

Cite this article:

Justice O., Emmanuel O.A. (2021), The Creation of Abelengro: A Cross-Cultural Art Music Composition. Journal of Advanced Research and Multidisciplinary Studies 1(1), 13-25. DOI: 10.52589/JARMSMZFLGSSM.

\section{Manuscript History}

Received: 17 April 2021

Accepted: 9 May 2021

Published: 14 May 2021

Copyright $\odot 2020$ The Author(s). This is an Open Access article distributed under the terms of Creative Commons Attribution-NonCommercialNoDerivatives 4.0 International (CC BY-NC-ND 4.0), which permits anyone to share, use, reproduce and redistribute in any medium, provided the original author and source are credited.
ABSTRACT: Ethnomusicology has an important mission of providing a body of musical knowledge that can be drawn on by artist-composers, performers, dancers as well as scholars in the field of music. The paper therefore presents an outcome of a creative ethnomusicological study of abele music among the Yeji people of the Bono-East Region in Ghana. Using Euba's theory of creative ethnomusicology and Nketia's concept of syncretism, the study highlights the indigenous elements of abele musical genre and unearths the process where these elements were used to create a musical artefact called Abelengro. Data for the study were collected through observation and adopted definitive analysis to provide the materials for the composition. The study revealed that Abele music contains rich source materials for creating a neoclassicism of African traditional music that could be enjoyed by a wide range of people. It is envisaged that these rich indigenous musical elements and idioms are harnessed by contemporary art musicians to achieve the uniqueness of African identity in art music compositions in Ghana.

KEYWORDS: Abele, Abelengro, Ethnomusicology, Yeji, BonoEast, Syncretism, Nchumburu 


\section{INTRODUCTION}

Creative ethnomusicology has usually made composers produce hybrid musical compositions by using the traditional materials of existing indigenous musical genres to make it unique (Acquah, 2018). It is one of the ways African art music composers use to identify their musical works as African. It is therefore very necessary for any composer to be seen as equally important as the music he or she creates since the end product of his or her effort brings knowledge and above all life to the society and this attests to the fact that music both internationally or locally is indeed life. The creative ethnomusicology is able to deal with the musicological and related creative arts content, the nature of historical advancement including influences, and the movement of the style between related and disparate cultures; the exponents of styles and express them through compositions. Exploring the valuable resources in contemporary art composition is part of the general intercultural trend, an approach to composition that is gaining grounds due to the increasing availability of African performers and recordings. This process has led to a new kind of art music that combines the received Western tradition as a result of the institutionalization of Western music, with indigenous resources. Exploring African musical resources has become part of an on-going cultural process in which the colonial experience is being reinterpreted alongside the rediscovery and use of traditional forms of expression (Nketia, 2004).

As indicated in Acquah and Boahen (2016), most of the art music composers in Ghana write works using Western classical techniques. Nevertheless, those who create works with traditional resources also fail to capture the inherent cultural nuances of the musical idioms of the concerned genre because of the bias from Western compositional techniques. There are many elements embedded in our Ghanaian traditional music that can be utilized by art music composers to make their works uniquely Ghanaian. Some of these idioms include call and response pattern of vocal music; the bell rhythm of gong; the predominant use of the pentatonic scale; the speech rhythm growing out of tonal inflections of African words; musical instruments used as symbols together with the use of polymetres and polyrhythms (Akpabot, 1986; Acquah $\&$ Boahen, 2016). So this research therefore, focuses on writing a classic dramatic musical work using indigenous materials but Western instruments. Our intention has been the documentation of Nchumburu traditional musical types by collecting Abele rhythmic patterns, themes of songs, as well as other fascinating ideas to create an extension of a hybrid musical artefact which is unique in nature. The purpose was to identify the various elements contained in the music and select some of which may be interesting in composing a new contemporary art musical piece. In this paper, the original composition, Abelengro, created was based on the elements of Abele songs. Etymologically, Abelengro is from two words: Abele and agro (play). Abelengro is therefore a musical play or drama from the Abele musical genre. The paper begins with the theoretical framework, related literature, methodology, the corpus used for the composition and a definitive analysis with excerpts from the composition. Thus, apart from analysing and highlighting the musical characteristics inherent in the Abele musical genre, it will venture into melodic and textual manipulations in the local idiom. This will afford the contemporary art musicians the opportunity to use such idioms to increase their repertoire of compositions. Indeed, equally importantly, the study will serve as a documentation of this fragile intangible cultural heritage of the people of Nchumburu. 


\section{Theoretical and Conceptual Frameworks}

One of the theories used in this work is the theory of creative ethnomusicology propounded by Euba (2001) and used in the work of Brukman (2017). Euba sees ethnomusicology as a process whereby information obtained from a music research is used in composition rather than as the basis of scholarly writing. This theory welds the contradiction between the ethnomusicologist who goes to the field to collect the necessary data and the composer who uses the data collected to compose. This Eubai represented in his opera called Chaka (1999) which is a fusion of the twentieth century technique with stylistic elements from African traditional music, particularly the music of Yoruba of Southern Nigeria (Omojola, 1995). This theory created a scaffold for the compositional design within which various parts of elements like pitch, melody, rhythm and texture interact in a very unique way to create a genius and emotional content associated with the Abelengro musical artefact.

The study was also based on the concept of syncretism (Nketia, 2007) where one's mode of expression and creative ideas are expanded through the use of traditional source materials. In this case, sources of sound, themes and procedures for Abelengro were collected from the idioms of an indigenous music and blended with Western materials. According to Nketia, listeners are usually more apt to respond favourably to music that speaks in the same way in which their native language flows, each having its own peculiar rhythmic flow or feel. Both creative ethnomusicology theory and the concept of syncretic approach underpinned the creation of Abelengro to communicate in an appropriate musical idiom. The close proximity was instrumental in synthesizing the various parts as in text and melody, rhythm and meter; then texture to bring out the Abele musical idioms in the composition alongside the Western compositional techniques.

\section{REVIEW OF RELATED LITERATURE}

The review considers views of various scholars on musical compositional process and the use of aspects of traditional music to integrate Western musical elements to create hybrid works.

\section{Compositional Process}

The process of musical creation has been investigated by several researchers. What is evident is that composition can either be 'working type' or an 'inspirational type' (Bennett, 1976)). No matter how one looks at it, composition can be described as a process. Composition, simply, is the act of bringing something into being which did not exist before. If one is using words, the outcome becomes a novel; if one is using colour, the result becomes a painting; but when one uses sounds, the emerging product becomes a musical piece. Composition is, in fact, a 'putting together' of materials (Kinderman, 1991).

Taking an even modest and subtle stand on the composing process, Bennett (1976, p.3) says "composing process involves, first, discovering a germinal idea". He says, a brief sketch of the germinal idea was often recorded, followed by a first draft of the work, elaboration, refinement of the first draft, and then completion of the final draft in addition to copying of the score. Compositional activity seems to occur most frequently in association with feelings of tranquillity, security, and relaxation. Bennett also tells us about the four basic steps in musical composition which have been cited in Andrews (2004). The first stage involves a productive 
mood, a condition of expectation that a composition is imminent. Composers frequently cycle in and out of productive moods, Andrews noted. Improvisation may help initiate a productive mood, as many variables such as time of day or season of the year.

The next stage in musical composition described by Subatin (2019) is musical conception, when subconscious themes, melodies, or ideas break through to consciousness and are seized by the conscious mind. A sketch of the musical idea is often attempted at this time. Sketches are stenographic excerpts of the musical idea rather than finished pictures. The actual composing process involves condensation and expansion of the musical figures evoked during musical conception. Many scholars agree that intellect is important across all stages of musical creation, but particularly during the actual composing process (Andrews, 2004; Bennett, 1976; Kinderman, 1991)

Misiani's et al. (2017) underscore that, music must be understood from the participant's point of view, a true understanding involves analysis within the context in which it is created and practiced. Therefore, the created music is influenced by the artist's understanding of the subject through experience and knowledge gained in that genre. Such experience, gained from casual, informal contacts or deliberate, organised instruction, is drawn upon for musical creativity as manifested in performance, response to musical stimuli as well as composition. However, things are different in the case of the Ghanaian composer because several Ghanaian art composers are subjected to the strict regimental rules imposed on them from the study of Harmony, Melody Writing, Counterpoint, Orchestration and Compositional Techniques by their teachers, a condition that stifled creativity only a few could stand out. Notwithstanding, other teachers in order to enhance creativity allow their composition students to be on their own by helping them develop their own style through relating to their ideas as well as searching more on their traditional sources.

Paynter (2002) also describes composing as an age-old natural process of thinking and making something. A similar view is shared by Bailey (2007) who posits that the objective of composing music is to express oneself while satisfying the audience on the other hand. Hung et al. (2019) defines composition as an original piece of music; a process of creating a new piece of music. Daynes (2011) describes composition as a process and a product in his investigation into the process of composition. Indeed, all these definitions refer to creativity, therefore if the African composer understands his native music well, his creative endeavours become very developed because understanding traditional music should not be divorced from the values of the society in which the music was derived. For instance, Chernoff (1979) observes that the Western perception of music tended to approach music cerebrally through the written score; and by assessing the performance, interpreting or reading of work with relatively strict non-physical conventions. Contrary, Agawu (2014) concedes that African music might not distinguish between formal considerations such as dance, music and perceptive listening; and certainly not the score. Instead, African music combines these elements into an entire experience. In Western music, a score usually contains essential symbols that are peculiar to it or necessary to communicate to performers. These symbols help the music to have direction and marks that are necessary for a work to be performed (Johnson, 1981). For example, a musical score might contain markings for intensity of sound (such as f, p) and different speeds (Allegro, Moderato) at which the music should be performed. The score might also contain markings for stress, repeats, pause, etc. In some cases, a performer is left to put these into effect at his or her own discretions. In the study, classical Western and contemporary music aspects 
such as harmonic texture and performance medium were incorporated in the composition alongside Abele musical idiom to give it artistic drive and focus.

\section{Works of Western Composers Influenced By Ghanaian Traditions}

Exploring African resources in contemporary compositions is, thus, part of a general intercultural trend in Western hemisphere, an approach to composition that is gaining ground because of increasing availability of African performers and recordings. The Western composers mentioned below were referenced because they were inspired by folk idioms and traditions of various communities in which they lived. The study refers to them for the sake of comparison even if they lived way back between the 18th and early 20 th centuries.

According to Mereku (1997), Ian Hall and Steve Reich had the opportunity to visit and research in Ghana. The former, one time the director of the Bloomsbury Society in London was born in Guyana and educated in Oxford University. He was appointed Director of Music at the famous Achimota School in Ghana between 1964 and 1966. This experience, Hall describes, provided catalytic upheaval in his musical personality. Precisely, he said. 'Ghana inspired my Psalm 150 in which I introduced, boma, mpintin, atumpan and donno (all drums found at the Asantehene's court) to accompany the chorus' (Mereku, 1997). On the other hand, Mereku also observed that Steve Reich in his research in Ghana, his preoccupation was on the fascinating four time embodied in a traditional dance of the agbadza dance (Mereku, 1997). This time underlines most of the works he wrote. Mereku (2012) again observes that Reich's works include New York Counterpoint (1985), Different Trains (1988), and The Cave (1993). He illuminates how Reich manipulates high-tech to "imitate and develop recorded sounds." By use of samplers and keys, the musicians, controlling fragments of recorded speech are able to alter the phrasing and tempo of the words, or play 'chords' of words or bits of words.

Commenting on other Western composers, Mereku (1997) indicates that the American composer, Roy Travis, did not only have the opportunity in the 1960's to record, transcribe and analyse sikyi, techema-chema, asafo and akJm dance patterns from an Ashanti master drummer called Kwasi Badu at the University of California in Los Angeles (UCLA) but also had the opportunity to record and transcribe Ewe genres like gakpa and adevu from the Ghanaian master drummer, Robert Ayitee. Among his compositions are African Sonata (1996) for Pianoforte, Duo Concertante for violin and piano-a three-movement work that utilizes gakpa and asafo dances in the first and last movements respectively. Each of the movements in his Switched-on-Ashanti is based on akJm and techema-chema sikyi dance patterns. Bayley and Dutiro (2016) consider Travis's full-length opera, the Black Bacchants, (in which African elements are used) as the most ambitious of his works. The work is scored for five principal singers, triple chorus and a full symphonic orchestra combined with a large ensemble of Ghanaian traditional instruments. Our intention about the composition that will emerge from the study was to use the Abele traditional musical idioms and features in a fusion of some Western music tradition and techniques to come out with hybridized contemporary art music.

\section{Art Music in Africa}

The focus of art music in Africa was characterized by exploration of new rhythms, styles, and sounds. According to Lu (2004) the issue of inheriting a compositional tradition is complex for the contemporary African composer. The term art music - or sometimes fine art music - is used for convenience of reference for music designed for intent listening or presentation as 
"concert" music, music in which expression of feeling is combined with a high level of craftsmanship and a sense of beauty. African art music therefore refers to works that manifest these attributes but which are rooted in the traditions of Africa.

Understanding and incorporation of traditional sources, composers are faced with the prospect of reconciling the influences of western music techniques, and other musical idioms. The integration of traditional music influences into contemporary compositions has become increasingly common to the African composer. While the issues of popular idioms have been explored in the past, the current musical vernacular is now often treated with the same reverence as traditional sources. Mereku (1997) commented on the need for the use of indigenous materials in compositions:

Therefore, exploring African musical resources in contemporary composition is part of an ongoing cultural process in which the colonial experience is reinterpreted alongside the rediscovery and the use of traditional forms of expression where the new age composer had to go to the traditional sources for creative ideas, sources of sounds, themes and procedures that may be useful for expanding the mode of his or her expression and blend these with Western contemporary compositional practice. (p.96)

The need to fuse Western and African elements represents the most important basis for this work. The combination of Western and African traditional instruments, the combination of diatonic, tonally, conceived harmonies and atonal textures, the use of inspired modal (harmonic and melodic) procedures and harmonic tonal features which suggest an affinity with Bar̂tok and Debussy are all guidelines of analysis in this work which symbolizes the spread through eclectics (Sadoh, 2007).

\section{METHODOLOGY}

The creative ethnomusicology involved three phases: Descriptive, Analytic and creative phases. At the descriptive phase, Abele traditional music performances were observed at the Kajoji festival. It also involved video recordings which incredibly were dance performances, a characteristic feature of music performed during the celebration, to dig up features amidst rhythmic motifs, phrases, themes, meter and other expressive elements. Live audio as well as video recordings of musical performances were done at the durbar grounds of the Kajoji festival from the beginning to the end of the ceremony with audio and video recorders respectively. Performances that met our desire were purposively recorded and transcribed with the Finale Music software. Data collected were analysed through the conventional analytical approaches proposed by Cook (1987) and used in the work of Musungu (2010). These conventional methods of analysis include macro analysis, extensional and intensional analyses. In the macro analysis, recorded musical performances were transcribed and notated in staff notation with the Finale music Software. Information like music structure and performance styles were noted. With the extensional analysis, there was the need to identify the Nchumburu traditional music and the associated sound culture that would inform the choice of scales and modes of the composition. Similarly, in the intensional analysis, qualities that depict Nchumburu folk music such as melodic and rhythmic patterns were emphasized.

The creative phase involved choice of instruments and rhythmic patterns, and more importantly, a created story to go with the composition. The reason is that most of the songs in 
the Abele ensemble have background stories. In our case, we created a story that would be appropriate for the instrumentation and the patterns used. The idea was to depict dramatic scenes by describing or enhancing a storyline; an idea propounded by Richard Wagner in the Romantic period of the Western Music history.

Story Title: The Animal Kingdom

\section{Synopsis of the Story}

Mr. Tiger was hunting for a long time for prey. He became happy when he spotted from far that Rat was approaching. So, he hid in an attempt to arrest Rat for his meal. Unfortunately for Mr. Tiger, Rat saw him and started to run away but the hungry and angry Tiger gave it a hot chase to catch the Rat since without it there was no food that day for him. In the course of running, the Tiger fell into a pit dug by the surveyors in the bush and that saved the Rat. The Tiger cried very loud for help. The Rat returned knowing very well that the Tiger had fallen into a pit and could not get him anymore, but saw the Tiger crying mercilessly for help so he decided to assist him. Tiger once again wanted to kill the rat after being saved but the rabbit appeared to the rescue of the Rat.

\section{Sections in the Story}

The story has six (6) sections (A, B, C, D, E \& F): the first section is the forest scene which comprises the windy environment and the usual sounds of the creatures of the forest. The second and third sections are the hunting expedition of Mr. Tiger while the fourth section is the unfortunate incident of the Tiger falling into the pit. The fifth section is the rescue as well as when he was wittingly asked to go back into the pit to be rescued for the second time. The sixth section narrates the struggles in the pit before he died finally.

\section{Instrumentation}

Woodwinds: Bassoon, contrabassoon.

Brass: Tuba

Percussions: Wind chimes, Agogo Bells, Gong, Guiro, Log Drum and Drum Set.

Strings: Violin, Viola, Cello and Double Bass.

These instruments were selected for their tone compatibility and effects to the scenes in the story. The music created has a performance duration of 7 minutes, 35 seconds. Some of the motives derived from abele musical ensemble are illustrated below: 


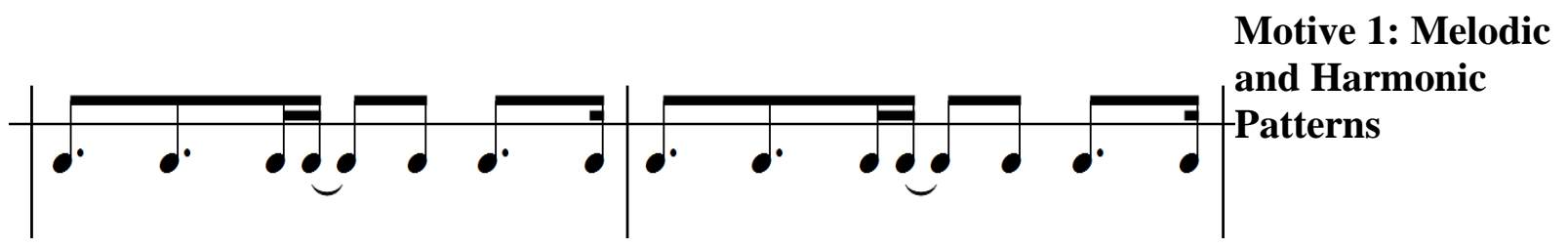

Motive 2: Bell Patterns

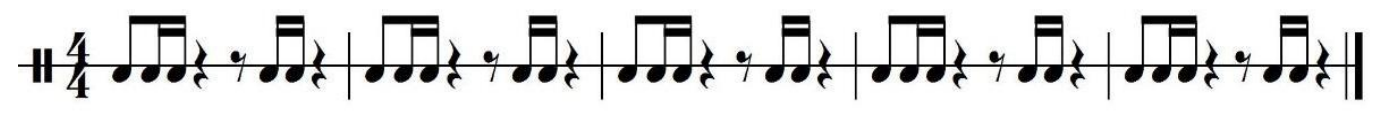

Motive 3: Drum Patterns
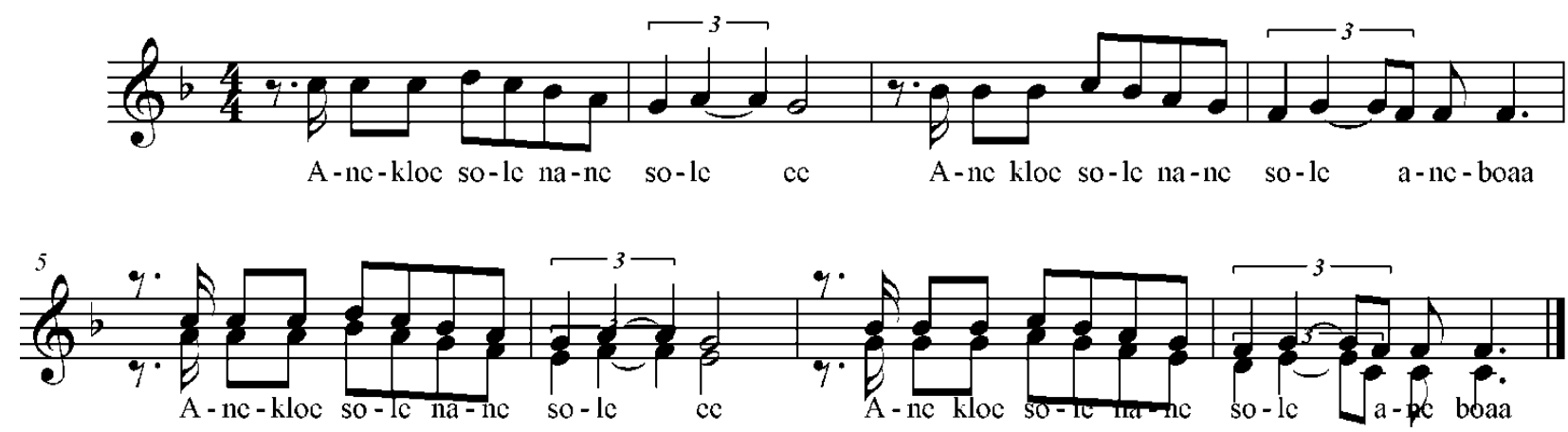

Sections of the Composition - Analysis

\section{SECTION A}

This section spans between bars 1 through to 40. The motivic movements were made up of sounds to scenically paint the Soundscape of birds, wild animals, and the movements to trees and other creatures exiting in the forest. Excerpt of the first section is seen in the example below. 
Journal of Advanced Research and Multidisciplinary Studies

Volume 1, Issue 1, 2021 (pp. 13-25)

\section{Excerpt 1: Activities in the forest}

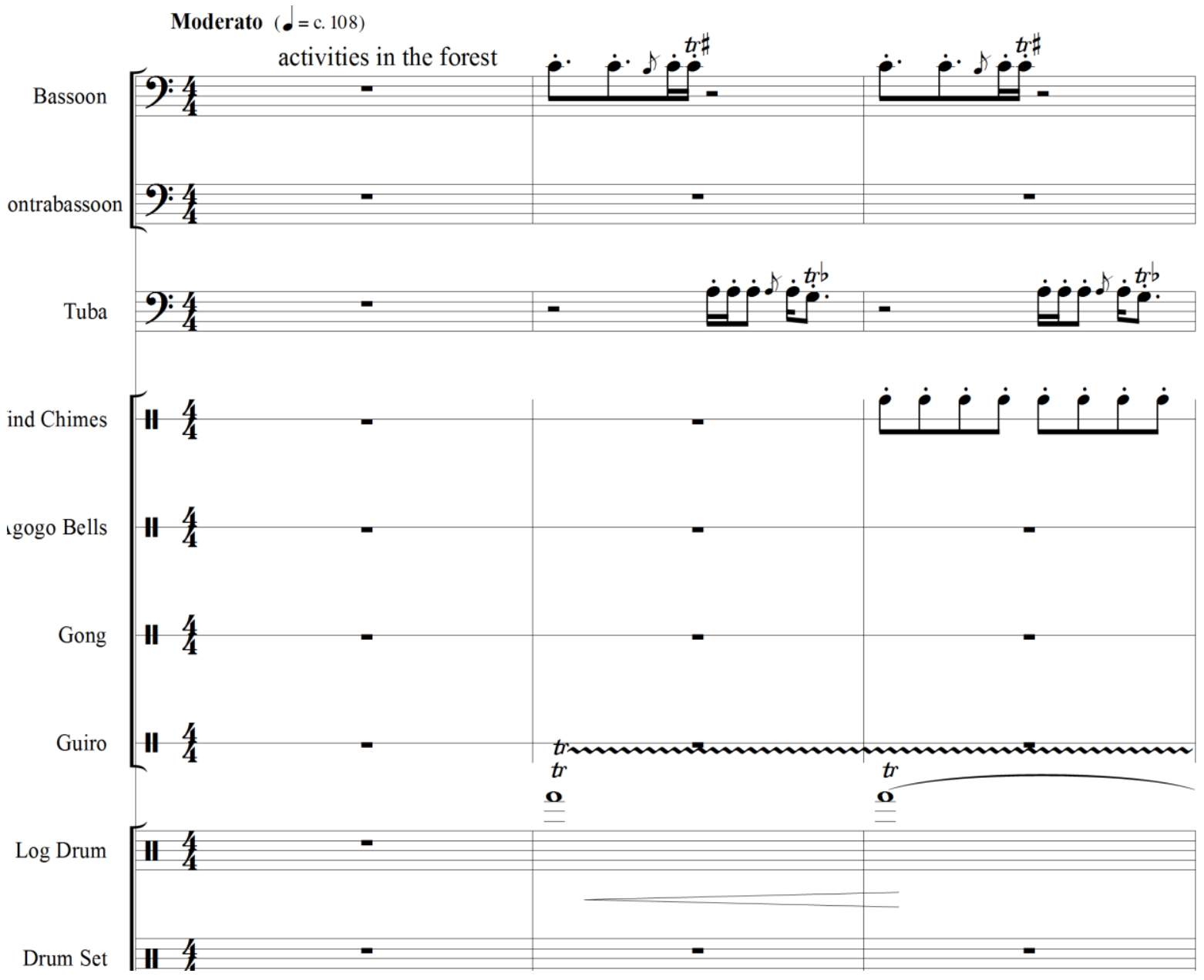

\section{SECTION B}

This section is the hunting expedition of Mr. Tiger whose presence frightened all smaller creatures to go into hiding. The section had some leitivotivic melodies as well as rhythms to imaginatively depict the scene. It is the hunting expedition of the Tiger starting from bar 46 to bar 100. The following is an excerpt. 


\section{Excerpt 2: The Hunting expedition}

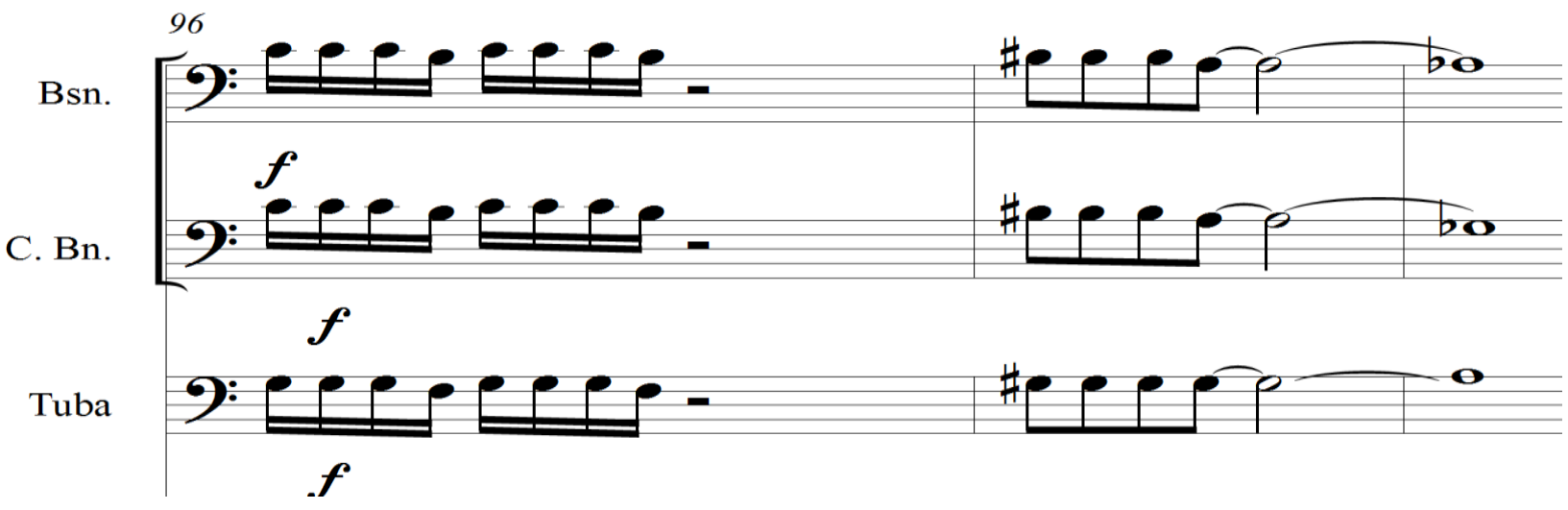

\section{SECTION C}

This section had to do with the coming in of other creatures and the attempt for the Tiger to give a hot chase to them. It also had some leitmotifs from Abele songs and patterns to tone paint the scene. It starts from bar 100 to bar 130. An excerpt of the section is illustrated below.

\section{Excerpt 3: Movement of Mr. Tiger and other Creatures}

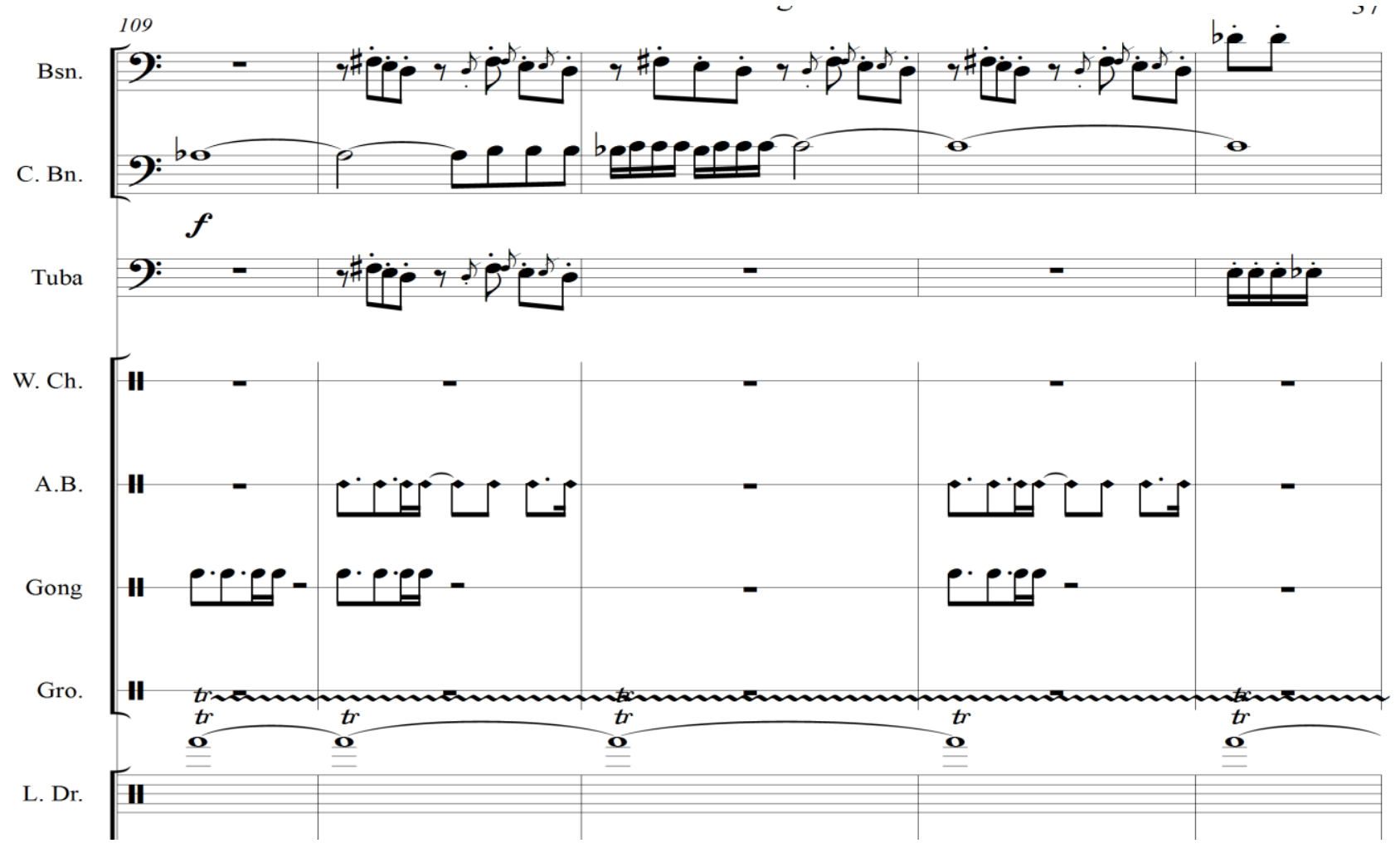




\section{SECTION D}

This is where the Tiger chased the rat and got drawn into a pit but the rat had mercy on the Tiger and decided to bring it up but the Tiger had it contrary as it wants to use the rat for meat. However, the rat was saved by the timely intervention of the witty rabbit. The section used the running note used by the drums of the abele to denote the hot chase and the struggle.

\section{Excerpt 4: Tiger falls into the pit}

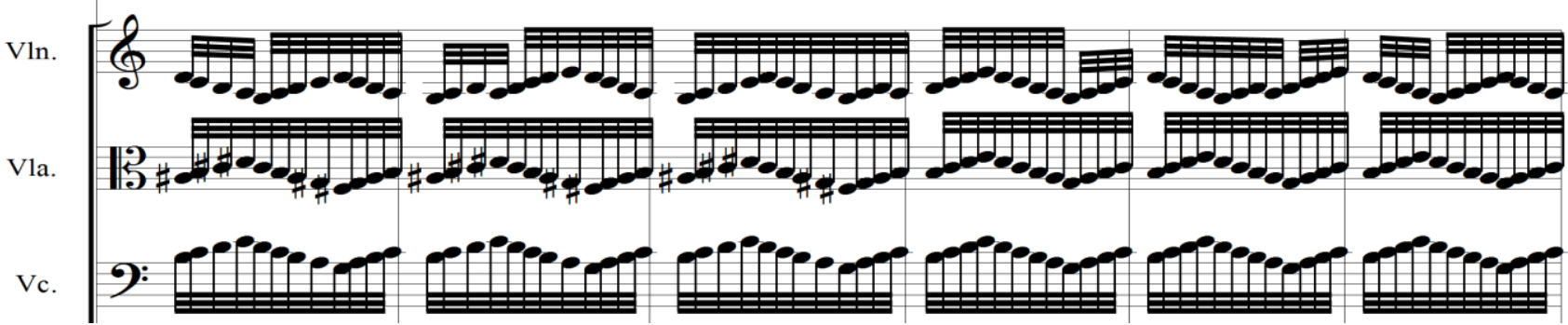

\section{SECTION E}

This section is where the Tiger was tricked to enter into the pit. The section uses a lot of polyrhythmic motifs from the patterns gathered from the music of the festival to tone paint the scene. It starts from bar 144 to bar 164.

\section{Excerpt 5: Tiger trapped into the pit again}

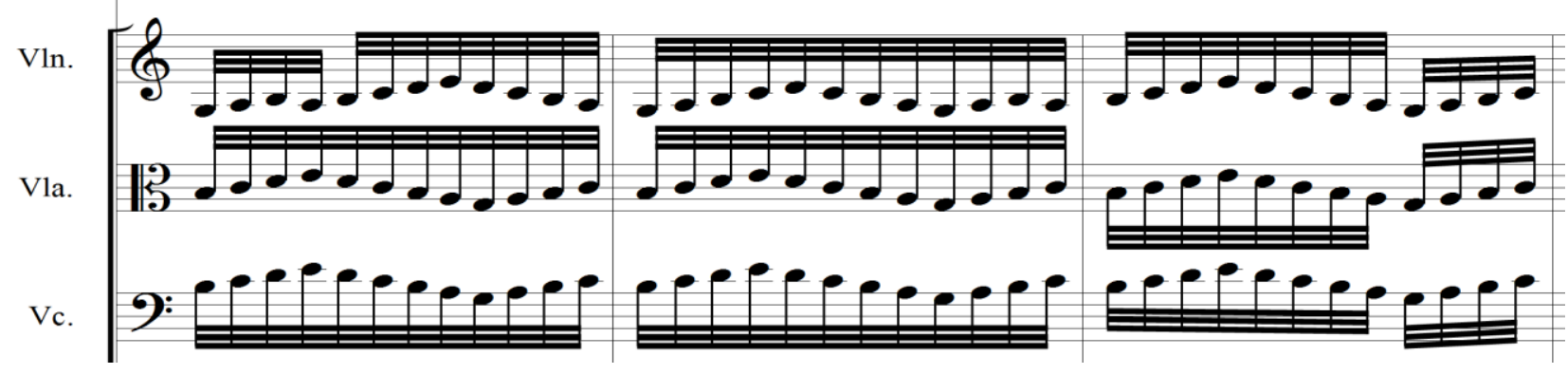

\section{SECTION F}

This is the last section of the original composition. It dealt with the tragedy of the Tiger where it had to die in the pit. It starts from the bar 165 to bar 200). It used polyrhythm and hokect techniques. 


\section{Excerpt 6: Tiger struggles and die}

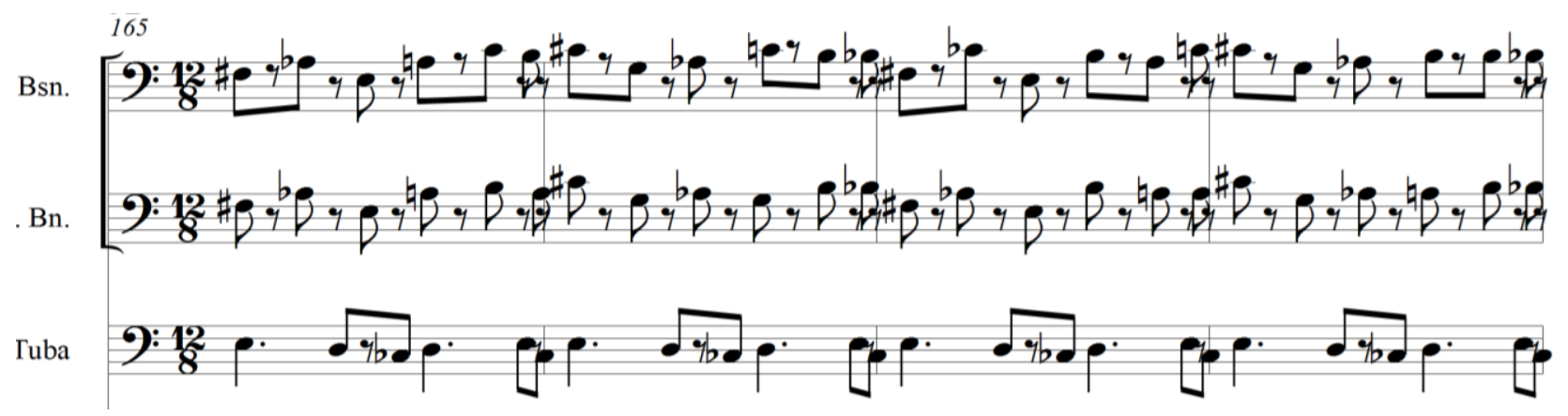

\section{CONCLUSION AND RECOMMENDATIONS}

The study discovers new and accumulative knowledge about Abele music of the Yeji traditional area as the patterns and idioms used in the composition could be introduced in other musical genres in the Yeji traditional area and the Nchumburu communities in general. Indeed, such compositions are palpable to promote and sustain the lost music in our oral tradition as well as maintain the dignity of our culture. Similarly, music of the Abele makes available some major linguistic material which would be useful when appropriate interest is given to them. Indeed, creative ethnomusicology and syncretic approach in art music compositions in Ghana can bring out the innovations which best fit the present thirst for the authentic Ghanaian art music identity. The harmonic and melodic pitch materials used were relatively diatonic moving in thirds, sixths and fourths. The homophony aspect relies heavily on the primary triads while the utilization of rhythmic motives and patterns regulated iambic cells in the dramatic scenes.

\section{REFERENCES}

Acquah, E. O., \& Boahen, E. (2017). Compositional processes of Xylafrique: A Contemporary Art Composition based on the Dagaaba gyil of Ghana. International Journal, 5(2), 15-32.

Acquah, E.O. (2018). Analytical pursuit of C.W.K. Mereku's 'Asomdwee Hen' Operetta. Journal of African Arts \& Culture, 2(1), 1-19.

Agawu, K. (2014). Representing African music: Postcolonial notes, queries, positions. Routledge.

Akpabot, S. E. (1986). Foundation of Nigerian traditional music. Spectrum Books.

Andrews, B. W. (2004). How composers compose: In search of the questions. Research and Issues in Music Education, 2(1), $\mathrm{n} 1$.

Bailey, P. (2007). Fats Waller meets Harry Champion: Americanization, national identity and sexual politics in inter-war British music hall. Cultural and Social History, 4(4), 495509.

Bayley, A., \& Dutiro, C. (2016). Developing dialogues in intercultural music-making.

Bennett, S. (1976). The process of musical creation: Interviews with eight composers. Journal of research in Music Education, 24(1), 3-13. 
Brukman, J. (2017). Creative ethnomusicology and African art music: a close musical reading of wood and clay, Kundi dreams and Umrhubhe Geeste by Anthony Caplan. African Music, 10(3).

Chernoff, J. M. (1979). African rhythm and African sensibility (Vol. 36). University of Chicago press.

Cook, N. (1987). Structure and performance timing in Bach's C major prelude (WTCI): an empirical study. Music Analysis, 6(3), 257-272.

Daynes, H. (2011). Listeners' perceptual and emotional responses to tonal and atonal music. Psychology of Music, 39(4), 468-502.

Euba, A. (2001). Text setting in African composition. Research in African Literatures, 32(2), 119-132.

Hung, Y. N., Chiang, I., Chen, Y. A., \& Yang, Y. H. (2019). Musical composition style transfer via disentangled timbre representations. arXiv preprint arXiv:1905.13567.

Johnson, R. (1981). The composer's advocate", by E. Leinsdorf (Book Review). Notes, 38(2), 312.

Kinderman, W. (Ed.). (1991). Beethoven's compositional process (Vol. 1). U of Nebraska Press.

Lu, M. Z. (2004). An essay on the work of composition: Composing English against the order of fast capitalism. College Composition and Communication, 16-50.

Mereku, C. (2012). Twenty-first-century African classicism: illustrations from the piano trio Pivicafrique on the theme of Jack Berry's 'Sasabonsam's Match'. Journal of the Musical Arts in Africa, 9(1), 39-61.

Mereku, C. W. K. (1997). A portfolio of musical compositions for a variety of forces including African instruments with commentary: A musico-ethnological approach to composition, with illustrations from original works-towards a new aesthetics. Unpublished doctoral thesis. Leeds: Leeds University.

Misiani's, O. F. D. O., Bim, B., \& Achieng Akuno, E. M. I. L. Y. (2017). Chapter nine controversial music: a postcolonial reading. Researching Music Censorship, 160.

Musungu, G. J. (2010). Elements of cross-cultural music composition: the creation of Esidialo--a Samia marriage suite (Doctoral dissertation).

Nketia, J. H. K. (2007). Developing contemporary idioms out of tradition. Music Survey in Historical Styles.

Nketia, J.H.K. (2004). African Art Music. Accra: Afram Publications (Ghana) Limited.

Omojola, B. (1995). Nigerian Art Music. Ibadan, Nigeria: Institut français de Recherche en Afrique (IFRA).

Paynter, J. (2002). Music in the school curriculum: why bother? British Journal of Music Education, 19(3), 215.

Sadoh, G. S. (2007). Intercultural Dimensions in Ayo Bankole's Music. iUniverse.

Subatin, J. (2019). The contemporary jazz composer: the importance of the conception of the source material in the compositional process (Doctoral dissertation, Instituto Politécnico de Lisboa-Escola Superior de Música de Lisboa). 